\title{
Individualized treatment of NSCLC: From research to clinical practice
}

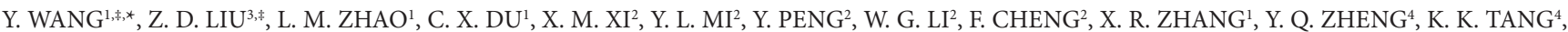 \\ H. Y. YANG ${ }^{4}$, D. T. CHU ${ }^{1}$ \\ ${ }^{1}$ Department of Medical Oncology, Cancer Institute (Hospital), Chinese Academy of Medical Sciences and Peking Union Medical College, Beijing, \\ China; ${ }^{2}$ Beijing Chaoyang District Shanhuan Cancer Hospital, Beijing, China; ${ }^{3}$ Beijing Chest Hospital, Capital Medical University, Beijing, China; \\ ${ }^{4}$ SureExam Bio-Tech Co., Guangzhou, Guangdong, China \\ *Correspondence: wangyanwenzhang@sina.cn \\ ${ }^{\ddagger}$ Contributed equally to this work.
}

Received November 27, 2012/ Accepted March 13, 2013

\begin{abstract}
The exact clinical significance of EGFR mutation status in NSCLC at the time of initial diagnosis remains disputable. The gene expression module in NSCLC for chemotherapy outcome prediction needs to be developed. We analyzed 56 patients with NSCLC received chemotherapy either with $(n=20)$ or without EGFR-TKIs $(n=36)$ between 2008 and 2012 in China. EGFR mutation test and gene expression profiling were performed in samples obtained before medication treatment by liquidchip platform. Significant association $(P=0.028)$ was seen between EGFR mutation status before first-line chemotherapy and EGFR-TKIs treatment outcomes, which even can be found from the status before second- or third-line treatment. A 14-gene expression profiling had been studied. Patients with low mRNA expression of ERCC1 or TYMS preferred higher DCR to cisplatin and pemetrexed than those with high expression $(P=0.39$ and $P=0.11)$. Highly co-expression of TUBB3 and STMN1 gene has associated with the resistance to antimicrotubule drugs $(P=0.03)$. Our data suggest the EGFR mutations status, even at the time of initial diagnosis, is predictive of outcomes of TKIs treatment after chemotherapy. The mRNA expression profiling investigated in this study has a predictive value in NSCLC treatment, but further research with expanded samples is still required.
\end{abstract}

Key words: non-small-cell lung cancer, EGFR mutation, TKIs, gene expression profiling, chemotherapy

Lung cancer has been the most common cancer, and is the leading cause of death all over the world [1]. In recent years, along with the rapid development of life science, the knowledge and requirement of clinical medicine has enhanced. Furthermore, The Human Genome Project has promoted the progress in pharmacogenetics and pharmacogenomics,

Abbreviations: NSCLC: non-small-cell lung cancer, EGFR: epidermal growth factor receptor, EGFR-TKIs : epidermal growth factor receptor-tyrosine kinase inhibitors, ERCC1: excision repair cross complementation 1, TYMS: thymidylate synthetase, RRM1: ribonucleotide reductase subunit M1, TUBB3: $\beta$-tubulin isotype III, STMN1: stathmin, ECOG: Eastern Cooperative Oncology Group, CAMS :Chinese Academy of Medical Sciences, CT : Computed tomography, CR :complete response, $\mathrm{PR}$ :partial response, SD : stable disease, PD :progressive disease, RECIST :Response Evaluation Criteria in Solid Tumors, BRCA1: breast cancer gene 1, TOP2A: Topoisomerase II $\alpha$

HER2: epidermal growth factor receptor 2, VEGFR2:Vascular endothelial growth factor receptor 2, PDGFR :platelet-derived growth factor receptor, IGF1R :Insulin-like Growth Factor receptor, FFPE :Formalin-fixed paraffinembedded, B2M :beta-2-microglobulin, TBP :TATA box binding protein , TFRC :transferrin receptor, DCR: disease control rate which makes the mode of medication treatment shift from diagnosis-directed drug therapy to gene-directed drug therapy on the basis of individual genetic characteristics. Oncology physicians are faced with the challenge of choosing the most effective anti-tumor agents for cancer patients to achieve the best possible outcome.

Previous studies on non-small-cell lung cancer (NSCLC) have identified the predictive value of EGFR (epidermal growth factor receptor) mutation for EGFR TKIs (epidermal growth factor receptor-tyrosine kinase inhibitors) - for example Gefitinib (Iresaa, AstraZeneca, UK). Determining optimal first-line therapy by these biomarkers is accepted as a standard for patients with NSCLC [2-7]. EGFR TKIs should be considered as the prior first-line treatments for the patients with EGFR mutation, while chemotherapy is superior to targeted therapy in the EGFR wild-type patients [8-9]. Because EGFR TKIs work only in some of the patients, the detection of EGFR mutation needs to be considered as essential routine before medication treatment. However, it remains unclear whether it is necessary 
and which sample is chosen for detection for the decision on EGFR-TKIs in second- or third-line treatment

Besides targeted therapy, the response to chemotherapy of NSCLC can also be predicted by some biomarkers. The mechanisms of many chemotherapy agents revealed by relevant genes which may influence drug response have been studied. The prediction of chemotherapy outcome based on gene expression level is becoming possible for many classes of chemotherapy agents. For example, ERCC1(excision repair cross complementation 1) expression has been association with cisplatin in patients with NSCLC $[10-14]$, gastric $[15,16]$, colorectal [19]; TYMS (thymidylate synthetase) expression has been association with fluorouracil/pemetrexed in many cancers [20-22]; RRM1(ribonucleotide reductase subunit M1) expression is connected with gemcitabine $[23,13]$, and TUBB3( $\beta$-tubulin isotype III) and STMN1(stathmin) are linked with paclitaxel/docetaxel [24-27]. In addition, multigene predictors for clinical outcome have been introduced to date, although none has become widely accepted [28-30]. However, now it is not possible to prospectively identify patients who can likely benefit from or suffer from certain chemotherapy in the clinical setting.

We retrospectively analyzed the data of NSCLC patients who received Gefitinib, as first-, second- or third-line treatment from January 2008 to May 2012 at our institution. We evaluated the predictive values of the EGFR mutation status at the time of initial diagnosis to Gefitinib treatment before and after chemotherapy. Meanwhile, we explored the association of a 14-gene expression profiling with the response of patients to Cisplatincontaining combination chemotherapy, pemetrexed-containing combination chemotherapy, or taxane-containing combination chemotherapy. The 14 genes which include TUBB3, EGFR, BRCA1(breast cancer gene 1), TOP2A (Topoisomerase II $\alpha$ ), RRM1, TYMS, STMN1, HER2 (epidermal growth factor receptor 2), VEGFR2 (Vascular endothelial growth factor receptor 2), KIT, PDGFR (platelet-derived growth factor receptor), VEGFR1, ERCC1 and IGF1R(Insulin-like Growth Factor receptor) have been reported as the biomarkers for NSCLC [10-16, 20-27, 42-49]. However, correlations of mRNA expression levels among these 14 genes and the efficacy of the 14-gene expression profiling on predicting chemotherapy outcomes have not been studied yet.

\section{Patients and methods}

Patients. We identified patients with NSCLC who had received chemotherapy and/or Gefitinib between January 2008 to May 2012 from the database of Cancer Institute and Hospital, Chinese Academy of Medical Sciences (CAMS). We analyzed the data of patients who were diagnosed with stage IV NSCLC. The performance status of all the patients was ECOG (Eastern Cooperative Oncology Group) grade 0-2. Finally, we gathered the data on 56 patients, of whom 52 patients had received chemotherapy as first-line treatment and 20 patients had received Gefitinib as first-, second- or third-line treatment.
Thirty-one patients had metastasis, and fifteen from them had more than two metastatic lesions.

Cisplatin-containing combination chemotherapy was administered in 26 patients (ERCC1 group) as the first-line chemotherapy, pemetrexed-containing combination chemotherapy in 26 patients (TYMS group) too, and taxane-containing combination chemotherapy in 27 patients (TUBB3 \& STMN1 group). Twenty patients received Gefitinib treatment. Computed tomography (CT) scans were performed at 4 weeks after treatment. The responses to treatment were classified as complete response (CR), partial response (PR), stable disease (SD), or progressive disease (PD) according to the Response Evaluation Criteria in Solid Tumors (RECIST) criteria. The institutional review board of CAMS approved this study.

EGFR mutation analysis and gene expression profiling. All the molecular analysis of this study were performed at SurExam Testing Center. The samples from enrolled patients were collected before medication treatment. Twenty-eight tumor samples were collected from the primary cancer by operation, twelve samples by transbronchial lung biopsy.

The presence of EGFR mutations in exons 18,19 and 21 was investigated. We gathered the mutational data of 20 patients with their informed consent. DNA extraction from paraffin-embedded tissues was performed using the Maxwell ${ }^{\circ}$ system (Promega, GA, USA). EGFR exons 18, 19 and 21 were screened using SurPlex ${ }^{\oplus}$-xTAG70plex (SurExam, GZ, China). The method includes five steps published in ref [31].

The mRNA expression profiling of 14 genes was determined by multiplex. branched-DNA liquidchip technology. Formalin-fixed paraffin-embedded (FFPE) tissue samples were processed by following steps. First the sample was homogenized in a mixture of homogenizing solution at $65^{\circ} \mathrm{C}$ for 2 hours. The homogenate was centrifuged to remove residual paraffin and debris, and then the supernatant was transferred to a fresh microcentrifuge tube. Forty $\mu \mathrm{l}$ sample homogenate was added to each well of a 96-well plate that contains following reagents in each well: $18.5 \mu \mathrm{l}$ of RNase-free water, $33.3 \mu \mathrm{l}$ of lysis solutions, $2 \mu \mathrm{l}$ of blocking reagent, $1 \mu \mathrm{l}$ of capture beads and $5 \mu \mathrm{l}$ of target gene-specific probe set. The plate was sealed and incubated for 18 hours at $54^{\circ} \mathrm{C}$ on a shaker with $750 \mathrm{rpm}$. The hybridization mixture was then removed to a filtered 96well plate. The un-bound RNA and other debris in wells were removed by washing three times with $250 \mu$ of wash buffer $(0.1 \times$ SSC and $0.03 \%$ lithium lauryl sulfate) under a vacuum system. Signals for the bound targeted mRNA were developed by following steps: 1) incubate in $100 \mu \mathrm{l}$ of pre-amplifier solution for 1 hour at $50^{\circ} \mathrm{C} ; 2$ ) wash twice with $200 \mu$ l wash buffer; 3) incubate in $100 \mu \mathrm{l}$ of amplifier solution for 1 hour at $50^{\circ} \mathrm{C}$; 4) wash twice with $200 \mu$ l wash buffer; 5) incubate in $100 \mu$ l of the labeled probe for 1 hour at $50^{\circ} \mathrm{C}$, and 6) wash twice with $200 \mu \mathrm{l}$ wash buffer. The samples were then incubated with $100 \mu \mathrm{l}$ $\mathrm{SA}-\mathrm{PE}$ solution at $50^{\circ} \mathrm{C}$ for $30 \mathrm{~min}$. The fluorescence value of each sample was analyzed by the Luminex 200 system. Control genes were beta-2-microglobulin (B2M), TATA box binding protein (TBP), and transferrin receptor (TFRC). 
Table 1 Patient characteristics

\begin{tabular}{|c|c|c|}
\hline & $\begin{array}{l}\text { No. of Gefitinib-treated } \\
\text { patients } \\
(\mathrm{N}=20)\end{array}$ & $\begin{array}{l}\text { No. of chemotherapy } \\
\text { patients } \\
(\mathrm{N}=52)\end{array}$ \\
\hline \multicolumn{3}{|l|}{ Age, year } \\
\hline Median & 58.5 & 55 \\
\hline Range & $44-81$ & $31-90$ \\
\hline$<60$ & 12 & 33 \\
\hline$\geq 60$ & 8 & 19 \\
\hline \multicolumn{3}{|l|}{ Gender } \\
\hline Male & 12 & 39 \\
\hline Female & 8 & 13 \\
\hline \multicolumn{3}{|l|}{ Smoking history } \\
\hline Smoker & 11 & 30 \\
\hline Never-Smoker & 8 & 18 \\
\hline Unknown & 1 & 4 \\
\hline \multicolumn{3}{|l|}{ Histologic } \\
\hline Adenocarcinoma & 17 & 39 \\
\hline Squamous cell carcinoma & 3 & 8 \\
\hline Unknown & 0 & 9 \\
\hline \multicolumn{3}{|l|}{ Performance status } \\
\hline 0 & 2 & 7 \\
\hline 1 & 10 & 29 \\
\hline 2 & 4 & 9 \\
\hline Unknown & 4 & 11 \\
\hline
\end{tabular}

Statistical analysis. All clinical data were collected independently by three physicians. The median value was used to divide the patients into high expression group and low expression group based on the mRNA expression level. The Fisher's exact test was used to determine the significant differences of TKI treatment effect between EGFR-mutated and wild-type group. The predictive effect of ERCC1, TYMS, TUBB3 and STMN1 mRNA expression was also explored in the chemotherapy population by Fisher's exact test. Spearman rank correlation distant was used to perform hierarchical clustering. Cluster analysis, heat-map and cluster-tree drawing was performed by $R$ bioconductor package. All other statistical analyses, performed using the SAS Business Analytics software 9.1, were two-sided, and $P<0.05$ was considered statistically significant.

\section{Results}

Patient characteristics. The patients consisted of 16 women and 40 men. There were 42 patients with lung adenocarcinomas; ten with squamous cell carcinomas; one adenosquamous carcinoma and three not clear. The baseline characteristics of the Gefitinib-treated and chemotherapy patients with NSCLC are listed in Table 1. There were 20 patients in Gefitinib-treated group. The median age was 58.5 years old and 12 of the patients were men. Seventeen patients had adenocarcinomas and eleven of the patients were smokers. Gefitinib was delivered as a firstline therapy in 8 patients, second-line therapy in 7 patients and third-line therapy in 5 patients. A total of 52 patients met the enrollment criteria and were entered into the chemotherapy group. Most of the patients received platinum-based doublet chemotherapy as first-line therapy. Two patients received cisplatin (1 patient) or pemetrexed (1 patient) monotherapy. Five patients received more than double chemotherapeutic agents.

EGFR mutation associated with response rate. Amongst the twenty cases in Gefitinib group, twelve patients had EGFR

Table 2. The tumor responsiveness and the patients' characteristics

\begin{tabular}{|c|c|c|c|c|c|c|c|}
\hline patient ID & mutation status & response & smoking history & age & gender & histology & Therapy line \\
\hline 9 & L858R & $\mathrm{PR}$ & never & 76 & female & Adeno & first \\
\hline 13 & $\Delta \mathrm{E} 746-\mathrm{A} 750(\mathrm{~K} 745: \mathrm{AAA})$ & $\mathrm{PR}$ & never & 58 & female & Adeno & first \\
\hline 16 & L858R & $\mathrm{PD}$ & Ex, 10 pack/yr & 67 & male & Adeno & second \\
\hline 17 & unknown & PD & never & 54 & female & Adeno & first \\
\hline 26 & $\Delta \mathrm{E} 746-\mathrm{A} 750(\mathrm{~K} 745: \mathrm{AAG})$ & PR & current & 44 & male & Adeno & second \\
\hline 27 & $\Delta \mathrm{E} 746-\mathrm{A} 750(\mathrm{~K} 745: \mathrm{AAA})$ & $\mathrm{SD}$ & never & 81 & female & Adeno & first \\
\hline 28 & $\Delta \mathrm{L} 747-\mathrm{S} 752$ ins $\mathrm{S}$ & SD & never & 69 & female & Adeno & first \\
\hline 29 & L858R & PR & $\mathrm{Ex}, 30 \mathrm{pack} / \mathrm{yr}$ & 60 & female & Adeno & second \\
\hline 30 & L858R & PR & current & 59 & female & Adeno & first \\
\hline 21 & L858R & $\mathrm{SD}$ & current & 59 & male & Adeno & second \\
\hline 42 & L858R & PR & current & 55 & male & Adeno & second \\
\hline 43 & unknown & PD & never & 47 & female & Adeno & second \\
\hline 2 & wild-type & SD & Ex, 23 pack/yr & 49 & male & Adeno & third \\
\hline 3 & wild-type & SD & never & 58 & male & Adeno & third \\
\hline 24 & wild-type & SD & $\mathrm{Ex}, 30 \mathrm{pack} / \mathrm{yr}$ & 63 & male & Squamous & first \\
\hline 35 & wild-type & SD & current & 47 & male & Adeno & first \\
\hline 18 & wild-type & $\mathrm{PD}$ & $\mathrm{Ex}, 30 \mathrm{pack} / \mathrm{yr}$ & 55 & male & Squamous & third \\
\hline 51 & wild-type & SD & current & 72 & male & Adeno & first/second \\
\hline 4 & wild-type & PD & current & 52 & male & Squamous & third \\
\hline 12 & wild-type & $\mathrm{PD}$ & never & 66 & male & Adeno & second \\
\hline
\end{tabular}




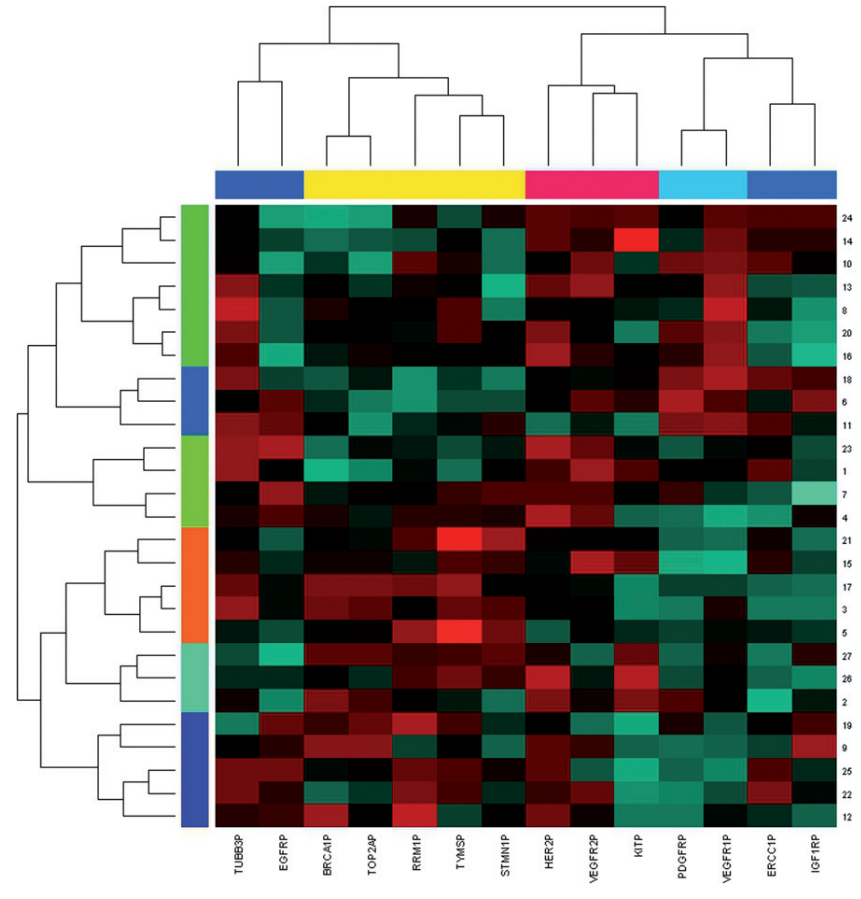

Figure 1. Identify tumor co-expression patterns based on 27 patients' gene expression modules.

The cells are colored according to Spearman's correlation coefficient values, with red indicating positive and green indicating negative correlations.

mutations. Six patients had EGFR exon 21 L858R point mutations and another four patients were exon 19 deletions. The tumor response was evaluated in 20 patients. Partial response (PR) was observed in six patients. There were eight patients with SD, and six patients with PD. Four of the six patients with PR had exon 21 L858R point mutations, and the other two had exon 19 deletions. However, three patients with PD also had EGFR mutations. Amongst the eight patients with $\mathrm{SD}$, five cases had no mutations and three cases had either EGFR exon 21 point mutations or exon 19 deletions. Table 2 shows the results of the tumor responsiveness and the patients' characteristics. Here we found the EGFR mutation status is associated with the efficacy of EGFR TKIs, which is consistent with previous research.

Gene expression module correlations and classification. The mRNA expression profiling of the 14 genes was determined in 27 patients who were treated with chemotherapy. The correlations between gene modules and the classification of patients were showed in Figure 1. The twenty-seven patients were divided into two groups based on the gene expression module. One group had 13 patients with high expression of TUBB3, EGFR, BRCA1, TOP2A, RRM1, TYMS and STMN1 gene, while low expression of HER2, VEGFR2, KIT, PDGFR, VEGFR1, ERCC1 and IGF1R gene. The other group had 14 patients with the correspondingly opposite expressions. $\mathrm{Pa}$ tients with tumors expressing the TUBB3-set signature had

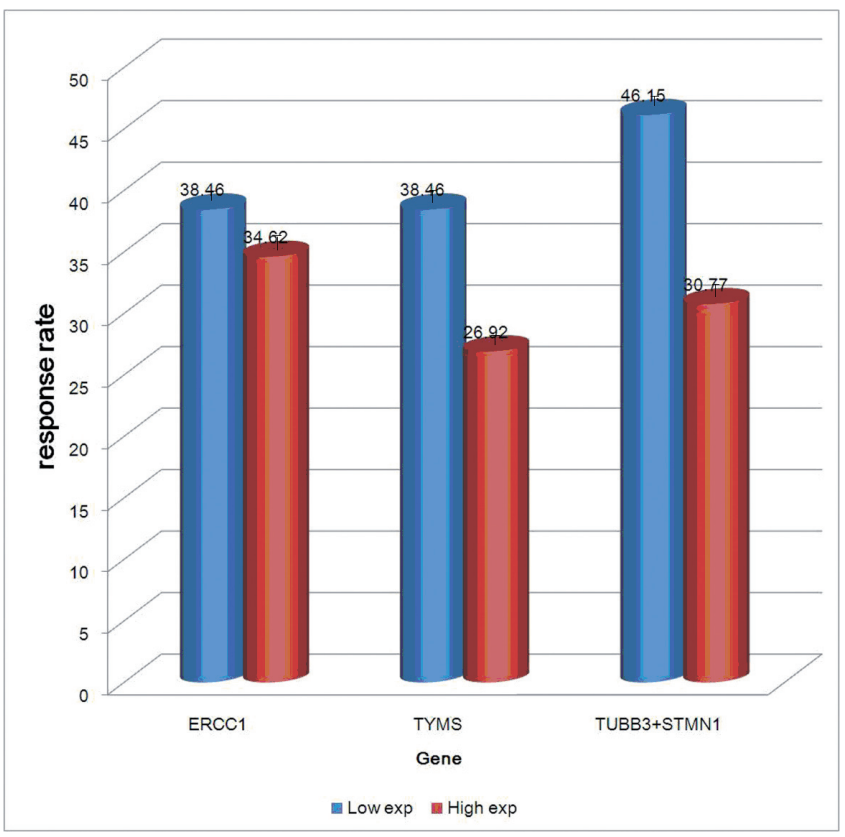

Figure 2. The comparison of DCR for high and low levels of ERCC1 and TYMS mRNA expression.

The disease control rate for high and low levels of ERCC1, TYMS and TUBB3 \&STMN1 mRNA expression was described and compared, with red indicating high expression, blue indicating low expression and the error bar indicating standard deviation.

a no significantly different response rate $(\mathrm{P}=0.109$, Mcnemar Test) to cisplatin-containing combination chemotherapy than patients with tumors without TUBB3-set signature expression. That indicates this Gene Expression Classification may predict the cisplatin-based chemotherapy effect correctly.

The mRNA expression of four genes (ERCC1, TYMS, TUBB3 and STMN1) was detected in 52 patients who received chemotherapy as first-line treatment. The ERCC1, TYMS, TUBB3 and STMN1 status was considered high expression if the mRNA expression level was equal or higher than the cut-off value, provided by SurExam Testing Center; otherwise, considered as low expression. The cut-off values to identify the high and low mRNA expression levels were 0.683 (range 0.256-1.533) for ERCC1, 0.172 (range 0.010-0.619) for TYMS, 0.2070 (range 0.047 - 1.346) for TUBB3 and 1.671 (range 0.8694.784) for STMN1, respectively.

Within the ERCC1 group, the disease control rate (DCR, $\mathrm{CR}+\mathrm{PR}+\mathrm{SD})$ was $73.08 \%(19 / 26)$. There was no patient with $\mathrm{CR}$, three patients with $\mathrm{PR}$, and sixteen with SD. Twelve of the nineteen patients had a low expression of ERCC1. We found that the patients with low-ERCC1 expression had a higher DCR than the others (83.3\% vs. $64.3 \%)$, but the difference was not statistically significant ( $P=0.39$, two-sided test). Similar results were observed in TYMS group. In the TYMS groups, the DCR were $65.38 \%$ (17/26). The patients with lower TYMS mRNA expression had a better outcome when treated with 
pemetrexed-based chemotherapy. However, there was no statistically significant differences either $(P=0.11$, two-sided test). Figure 2 showed the comparison of DCR for high and low levels of ERCC1 and TYMS mRNA expression. In the TUBB3 \&STMN1 group, neither TUBB3 nor STMN1 mRNA expression demonstrated a predictive value to taxane-containing combination chemotherapy. However, patients with co-expression of the two genes showed a trend of worse DCR to the others. Furthermore, the DCR was lowest in patients with low expression of both genes.

\section{Discussion}

The present study investigates some molecular biomarkers and their response biomarkers in advanced NSCLC. Numerous studies reported that patients with EGFR mutation had a better response to EGFR TKIs. In this study, we found statistical association between the EGFR mutation status and the outcomes of patients treated with Gefitinib, which is consistent with previous studies [2-7].

With the development of clinical research and basic research in biology, the consensus of identifying EGFR mutation status before EGFR TKIs treatment has been accepted widely. The National Comprehensive Cancer Network has approved gefitinib/erlotinib to be a first-line treatment choice for patients with advanced NSCLC with EGFR mutation. They even defined the testing method for EGFR. However, the time of the testing sample to obtain has not been standardized. A recent study investigated the influence of chemotherapy on EGFR mutations in patients with NSCLC [32]. They analyzed two cohorts: advanced NSCLC who received first-line chemotherapy with matched pre- and post-chemotherapy blood samples, and IIB to IIIB NSCLC with pre- and postneoadjuvant chemotherapy tumor tissues. The results showed that the EGFR mutation rates in both groups were decreased significantly. Therefore, they came to a conclusion that chemotherapy may alter the EGFR mutation status in patients with NSCLC. EGFR mutation status at the time of initial diagnosis couldn't predict the outcome of EGFR-TKIs as second- or third-line treatment. At last, they suggested that future prospective trials should consider analyzing biopsies taken immediately before second- or third-line EGFR-TKI therapy. Nevertheless, it's difficult to obtain tumor tissues from patients with advanced or recurrent NSCLC. Although several studies have focused on exploring the potential possibility of detecting EGFR mutation in circulating tumor DNA from plasma or other non-tissue samples, the concordance rate of EGFR mutation status between these samples and matched tumor tissue were not stable, varying from 59.1\% to $92 \%$ [33-36]. It seems that assessing EGFR mutation status using blood sample is not absolutely accurate. This retrospective study showed that the EGFR mutation status at the time of initial diagnosis can predict the efficacy of EGFR-TKI as second- or third-line therapy. It may provide useful information for decision-making on EGFR-TKI therapy when the detection in blood sample is unstable. In addition, the bloodbased testing need advanced technology and cost high, which limits the clinical application. For some medical institutions lacking of advanced technology, the tumor tissue obtained at the time of diagnosis is an alternative sample for molecular determining. Therefore, our current study suggests that the EGFR mutation status at the time of initial diagnosis is still useful to predict the efficacy of EGFR-TKI as second- or third-line therapy.

Previous study found that higher levels of ERCC1 expression are associated with poor response to platinum-based chemotherapy in advanced NSCLC [10]. Later studies confirmed the predictive role of ERCC1 in NSCLC $[12,37]$ and other types of cancer, such as colorectal cancer [17], gastric carcinoma [16,38-39], and esophageal cancer [40]. Our study showed that patients with lower expression of ERCC1 had relatively higher DCR than patients with higher gene expression when they received platinum-based chemotherapy, which is consistent with previous studies. But the difference between the two groups did not reach statistical significance. Some researches linked the pemetrexed resistance to TYMS expression levels in NSCLC $[20,41]$. We also found that the patients in the low-TYMS group had a higher DCR compared with the ones in the high group. However, our results did not show any statistically significant correlation between TYMS expression and clinical outcome. As the sample size of this study is small and lacks of statistical significance, the cut-off value provided might not be suitable for it.

The mechanism of chemotherapy drug functioning in vivo is complex and multi-gene involved, and more and more genes are revealed the impact on chemotherapy outcomes. With the development of relevant researches and the deep understanding of correlation among genes, it is more valuable to use multi-gene module to predict the outcomes of chemotherapy than single gene, although the latter is applied widely in chemotherapy selection. In our study, we established a 14-gene expression module, and found it had a better guide to predict the chemotherapy outcomes. Multi-gene expression profiling may be a useful tool for chemotherapy and the tendency in future. In our opinion, multi-gene expression possesses the advantage of depicting the full-scale gene expression characteristics systemically. Further study is needed to optimize the module.

In conclusion, the present study did not reveal a significant clinical impact of the gene expression of ERCC1 or TYMS on advanced NSCLC patients treated with cisplatin-based or pemetrexed-based first-line chemotherapy. However, we reported significantly different DCR of first-, second- or thirdline EGFR-TKI therapy according to the EGFR mutation status at the time of diagnosis in the patients with advanced stage, suggesting that the mutation of the EGFR gene determined using tumor tissue of diagnosis may predict the response to second- or third-line EGFR-TKI therapy. The 14-gene expression module established in this study might be useful for predicting chemotherapy outcomes. 
Acknowledgements: The authors sincerely thank other physicians and investigators for their technical supports and contributions to this study.

\section{References}

[1] SIEGEL R, NAISHADHAM D, JEMAL A. Cancer statistics, 2012. CA Cancer J Clin 2012; 62: 10-29. http://dx.doi. org/10.3322/caac. 20138

[2] SHARMA SV, BELL DW, SETTLEMAN J, HABER DA. Epidermal growth factor receptor mutations in lung cancer. Nat Rev Cancer 2007; 7: 169-81. http://dx.doi.org/10.1038/nrc2088

[3] MITSUDOMI T, YATABE Y. Mutations of the epidermal growth factor receptor gene and related genes as determinants of epidermal growth factor receptor tyrosine kinase inhibitors sensitivity in lung cancer. Cancer Sci 2007; 98: 1817-24. http://dx.doi.org/10.1111/j.1349-7006.2007.00607.x

[4] HIRSCH FR, VARELLA-GARCIA M, BUNN PA, JR., FRANKLIN WA, DZIADZIUSZKO R et al. Molecular predictors of outcome with gefitinib in a phase III placebo-controlled study in advanced non-small-cell lung cancer. J Clin Oncol 2006; 24: 5034-42. http://dx.doi.org/10.1200/JCO.2006.06.3958

[5] LYNCH TJ, BELL DW, SORDELLA R, GURUBHAGAVATULA S, OKIMOTO RA et al. Activating mutations in the epidermal growth factor receptor underlying responsiveness of non-small-cell lung cancer to gefitinib. N Engl J Med 2004; 350: 2129-39. http://dx.doi.org/10.1056/NEJMoa040938

[6] PAEZ JG, JANNE PA, LEE JC, TRACY S, GREULICH H et al. EGFR mutations in lung cancer: correlation with clinical response to gefitinib therapy. Science 2004; 304: 1497-500. http://dx.doi.org/10.1126/science.1099314

[7] PAO W, MILLER V, ZAKOWSKI M, DOHERTY J, POLITI $\mathrm{K}$ et al. EGF receptor gene mutations are common in lung cancers from "never smokers" and are associated with sensitivity of tumors to gefitinib and erlotinib. Proc Natl Acad Sci U S A 2004; 101: 13306-11. http://dx.doi.org/10.1073/ pnas. 0405220101

[8] GRIDELLI C, CIARDIELLO F, GALLO C, FELD R, BUTTS $\mathrm{C}$ et al. First-Line Erlotinib Followed by Second-Line Cisplatin-Gemcitabine Chemotherapy in Advanced NonSmall-Cell Lung Cancer: The TORCH Randomized Trial. J Clin Oncol 2012; 30: 3002-11. http://dx.doi.org/10.1200/ LCO.2011.41.2056

[9] GRIDELLI C, BUTTS C, CIARDIELLO F, FELD R, GALLO $\mathrm{C}$ et al. An international, multicenter, randomized phase III study of first-line erlotinib followed by second-line cisplatin/ gemcitabine versus first-line cisplatin/gemcitabine followed by second-line erlotinib in advanced non-small-cell lung cancer: treatment rationale and protocol dynamics of the TORCH trial. Clin Lung Cancer 2008; 9: 235-8. http://dx.doi. org/10.3816/CLC.2008.n.037

[10] LORD RV, BRABENDER J, GANDARA D, ALBEROLA V, CAMPS C et al. Low ERCC1 expression correlates with prolonged survival after cisplatin plus gemcitabine chemotherapy in non-small cell lung cancer. Clin Cancer Res 2002; 8: 2286-91.

[11] WACHTERS FM, WONG LS, TIMENS W, KAMPINGA HH, GROEN HJ. ERCC1, hRad51, and BRCA1 protein expression in relation to tumour response and survival of stage III/IV NSCLC patients treated with chemotherapy. Lung Cancer 2005; 50: 211-9. http://dx.doi.org/10.1016/ j.lungcan.2005.06.013

[12] OLAUSSEN KA, DUNANT A, FOURET P, BRAMBILLA E, ANDRE F et al. DNA repair by ERCC1 in non-small-cell lung cancer and cisplatin-based adjuvant chemotherapy. $\mathrm{N}$ Engl J Med 2006; 355: 983-91. http://dx.doi.org/10.1056/ NEJMoa060570

[13] ROSELL R, DANENBERG KD, ALBEROLA V, BEPLER G, SANCHEZ JJ et al. Ribonucleotide reductase messenger RNA expression and survival in gemcitabine/cisplatin-treated advanced non-small cell lung cancer patients. Clin Cancer Res 2004; 10: 1318-25. http://dx.doi.org/10.1158/1078-0432. CCR-03-0156

[14] FUJII T, TOYOOKA S, ICHIMURA K, FUJIWARA Y, HOTTA $\mathrm{K}$ et al. ERCC1 protein expression predicts the response of cisplatin-based neoadjuvant chemotherapy in non-small-cell lung cancer. Lung Cancer 2008; 59: 377-84. http://dx.doi. org/10.1016/j.lungcan.2007.08.025

[15] METZGER R, LEICHMAN CG, DANENBERG KD, DANENBERG PV, LENZ HJ et al. ERCC1 mRNA levels complement thymidylate synthase mRNA levels in predicting response and survival for gastric cancer patients receiving combination cisplatin and fluorouracil chemotherapy. J Clin Oncol 1998; 16: 309-16.

[16] KWON HC, ROH MS, OH SY, KIM SH, KIM MC et al. Prognostic value of expression of ERCC1, thymidylate synthase, and glutathione S-transferase P1 for 5-fluorouracil/oxaliplatin chemotherapy in advanced gastric cancer. Ann Oncol 2007; 18: 504-9. http://dx.doi.org/10.1093/annonc/mdl430

[17] KIM SH, KWON HC, OH SY, LEE DM, LEE S et al. Prognostic value of ERCC1, thymidylate synthase, and glutathione Stransferase pi for 5-FU/oxaliplatin chemotherapy in advanced colorectal cancer. Am J Clin Oncol 2009; 32: 38-43. http:// dx.doi.org/10.1097/COC.0b013e31817be58e

[18] CHANG PM, TZENG CH, CHEN PM, LIN JK, LIN TC et al. ERCC1 codon $118 \mathrm{C}-->\mathrm{T}$ polymorphism associated with ERCC1 expression and outcome of FOLFOX-4 treatment in Asian patients with metastatic colorectal carcinoma. Cancer Sci 2009; 100: 278-83. http://dx.doi.org/10.1111/j.13497006.2008.01031.x

[19] DABHOLKAR M, BOSTICK-BRUTON F, WEBER C, BOHR VA, EGWUAGU C et al. ERCC1 and ERCC2 expression in malignant tissues from ovarian cancer patients. J Natl Cancer Inst 1992; 84: 1512-7. http://dx.doi.org/10.1093/ jnci/84.19.1512

[20] BEPLER G, SOMMERS KE, CANTOR A, LI X, SHARMA A et al. Clinical efficacy and predictive molecular markers of neoadjuvant gemcitabine and pemetrexed in resectable non-small cell lung cancer. J Thorac Oncol 2008; 3: 1112-8. http://dx.doi.org/10.1097/JTO.0b013e3181874936

[21] WATSON RG, MUHALE F, THORNE LB, YU J, O'NEIL BH et al. Amplification of thymidylate synthetase in metastatic colorectal cancer patients pretreated with 5-fluorouracil-based chemotherapy. Eur J Cancer 2010; 46: 3358-64. http://dx.doi. org/10.1016/j.ejca.2010.07.011 
[22] JENSEN SA, VAINER B, WITTON CJ, JORGENSEN JT, SORENSEN JB. Prognostic significance of numeric aberrations of genes for thymidylate synthase, thymidine phosphorylase and dihydrofolate reductase in colorectal cancer. Acta Oncol 2008; 47: 1054-61. http://dx.doi.org/ 10.1080/02841860801942158

[23] BEPLER G, KUSMARTSEVA I, SHARMA S, GAUTAM A, CANTOR A et al. RRM1 modulated in vitro and in vivo efficacy of gemcitabine and platinum in non-small-cell lung cancer. J Clin Oncol 2006; 24: 4731-7. http://dx.doi. org/10.1200/JCO.2006.06.1101

[24] SEVE P, ISAAC S, TREDAN O, SOUQUET PJ, PACHECO $\mathrm{Y}$ et al. Expression of class III \{beta\}-tubulin is predictive of patient outcome in patients with non-small cell lung cancer receiving vinorelbine-based chemotherapy. Clin Cancer Res 2005; 11: 5481-6. http://dx.doi.org/10.1158/1078-0432.CCR05-0285

[25] SEVE P, MACKEY J, ISAAC S, TREDAN O, SOUQUET PJ et al. Class III beta-tubulin expression in tumor cells predicts response and outcome in patients with non-small cell lung cancer receiving paclitaxel. Mol Cancer Ther 2005; 4: 2001-7. http://dx.doi.org/10.1158/1535-7163.MCT-05-0244

[26] WANG LF, YIN HT, QIAN XP, WEI J, ZHAO Y et al. betaTubulin III mRNA expression and docetaxel sensitivity in non-small cell lung cancer. Clin Invest Med 2009; 32: E278.

[27] ALLI E, BASH-BABULA J, YANG JM, HAIT WN. Effect of stathmin on the sensitivity to antimicrotubule drugs in human breast cancer. Cancer Res 2002; 62: 6864-9.

[28] OSHITA F, IKEHARA M, SEKIYAMA A, HAMANAKA N, SAITO $\mathrm{H}$ et al. Genomic-wide cDNA microarray screening to correlate gene expression profile with chemoresistance in patients with advanced lung cancer. J Exp Ther Oncol 2004; 4: 155-60.

[29] BEER DG, KARDIA SL, HUANG CC, GIORDANO TJ, LEVIN AM et al. Gene-expression profiles predict survival of patients with lung adenocarcinoma. Nat Med 2002; 8: 816-24.

[30] CHEN HY, YU SL, CHEN CH, CHANG GC, CHEN CY, et al. A five-gene signature and clinical outcome in non-small-cell lung cancer. N Engl J Med 2007; 356: 11-20. http://dx.doi. org/10.1056/NEJMoa060096

[31] LI G, LUO X, HE J, ZHU Z, YU G et al. A novel liquidchip platform for simultaneous detection of 70 alleles of DNA somatic mutations on EGFR, KRAS, BRAF and PIK3CA from formalin-fixed and paraffin-embedded slides containing tumor tissue. Clin Chem Lab Med 2011; 49: 191-5. http://dx.doi. org/10.1515/cclm.2011.040

[32] BAI H, WANG Z, CHEN K, ZHAO J, LEE JJ et al. Influence of Chemotherapy on EGFR Mutation Status Among Patients With Non-Small-Cell Lung Cancer. J Clin Oncol 2012; 30: 3077-83. http://dx.doi.org/10.1200/JCO.2011.39.3744

[33] BAI H, MAO L, WANG HS, ZHAO J, YANG L et al. Epidermal growth factor receptor mutations in plasma DNA samples predict tumor response in Chinese patients with stages IIIB to IV non-small-cell lung cancer. J Clin Oncol 2009; 27: 2653-9. http://dx.doi.org/10.1200/JCO.2008.17.3930

[34] KIMURA H, SUMINOE M, KASAHARA K, SONE T, ARAYA $\mathrm{T}$ et al. Evaluation of epidermal growth factor receptor mu- tation status in serum DNA as a predictor of response to gefitinib (IRESSA). Br J Cancer 2007; 97: 778-84. http://dx.doi. org/10.1038/sj.bjc.6603949

[35] YUNG TK, CHAN KC, MOK TS, TONG J, TO KF et al. Single-molecule detection of epidermal growth factor receptor mutations in plasma by microfluidics digital PCR in non-small cell lung cancer patients. Clin Cancer Res 2009; 15: 2076-84. http://dx.doi.org/10.1158/1078-0432.CCR-08-2622

[36] GOTO K, ICHINOSE Y, OHE Y, YAMAMOTO N, NEGORO $S$ et al. Epidermal growth factor receptor mutation status in circulating free DNA in serum: from IPASS, a phase III study of gefitinib or carboplatin/paclitaxel in non-small cell lung cancer. J Thorac Oncol 2012; 7: 115-21. http://dx.doi. org/10.1097/JTO.0b013e3182307f98

[37] REYNOLDS C, OBASAJU C, SCHELL MJ, LI X, ZHENG $\mathrm{Z}$ et al. Randomized phase III trial of gemcitabine-based chemotherapy with in situ RRM1 and ERCC1 protein levels for response prediction in non-small-cell lung cancer. J Clin Oncol 2009; 27: 5808-15. http://dx.doi.org/10.1200/ LCO.2009.21.9766

[38] WEI J, ZOU Z, QIAN X, DING Y, XIE L et al. ERCC1 mRNA levels and survival of advanced gastric cancer patients treated with a modified FOLFOX regimen. Br J Cancer 2008; 98: 1398-402. http://dx.doi.org/10.1038/sj.bjc.6604317

[39] YUN J, KIM KM, KIM ST, KIM JH, KIM JA et al. Predictive value of the ERCC1 expression for treatment response and survival in advanced gastric cancer patients receiving cisplatin-based first-line chemotherapy. Cancer Res Treat 2010; 42: 101-6. http://dx.doi.org/10.4143/crt.2010.42.2.101

[40] FAREED KR, AL-ATTAR A, SOOMRO IN, KAYE PV, PATEL J et al. Tumour regression and ERCC1 nuclear protein expression predict clinical outcome in patients with gastro-oesophageal cancer treated with neoadjuvant chemotherapy. Br J Cancer 2010; 102: 1600-7. http://dx.doi.org/10.1038/sj.bjc.6605686

[41] JOERGER M, OMLIN A, CERNY T, FRUH M. The role of pemetrexed in advanced non small-cell lung cancer: special focus on pharmacology and mechanism of action. Curr Drug Targets 2010; 11: 37-47. http://dx.doi.org/10.2174/ $\underline{138945010790030974}$

[42] PIRKER R, PEREIRA JR, VON PAWEL J, KRZAKOWSKI M, RAMLAU R et al. EGFR expression as a predictor of survial for first-line chemotherapy plus cetuximab in patients with advanced non-small-cell lung cancer: analysis of data from the phase 3 FLEX study. Lancet Oncol. 2012; 13: 33-42. http://dx.doi.org/10.1016/S1470-2045(11)70318-7

[43] ROSELL R, SKRZYPSKI M, JASSEM E, TARON M, BARTOLUCCI $\mathrm{R}$ et al, BRCA1: A novel prognostic factor in resected non-small cell lung cancer . PLoS One. 2007; 2: 1129-35. http://dx.doi.org/10.1371/journal.pone.0001129

[44] DARASELIA N, WANG Y, BUDOFF A, LiTUEV A, POTAPOVA $O$ et al, Pathway analysis of primary human non-small cell lung cancer (NSCLC). J Clin Oncol. 2011; 29: No 15_suppl

[45] COX G, VYBERG M, MELGAARD B, ASKAA J, OSTER A et al, Herceptest: Her2 expression and gene amplification in non-small cell lung cancer. Int. J. Cancer. 2001; 92: 480-3 http://dx.doi.org/10.1002/ijc.1214 
[46] TANNO S, OHSAKI Y, NAKANISHI K, TOYOSHIMA E, KIKUCHI K, Human small cell lung cancer cells express functional VEGF receptors, VEGFR-2 and VEGFR-3. Lung Cancer. 2004; 46: 11-9 http://dx.doi. org/10.1016/j.lungcan.2004.03.006

[47] YOO J, KIM CH, SONG SH, SHIM BY, JEONG YJ et al, Expression of c-kit and p53 in non-small cell lung cancers. Cancer Res Treat. 2004; 36: 167-72. http://dx.doi.org/10.4143/ crt.2004.36.3.167
[48] BAUMAN J, EATON K AND MARTINS R, Antagonism of Platelet-derived growth factor receptor in non-small cell lung cancer: rationale and investigations. Clin Cancer Res. 2007; 13: 4632-36. http://dx.doi.org/10.1158/1078-0432.CCR-07$\underline{0212}$

[49] NAKAGAWA M, URAMOTO H, OKA S, CHIKAISHI Y, IWANAMI T et al, Clinical significance of IGF1R expression in non-small-cell lung cancer. Clin Lung Cancer. 2012; 13: 136-42. http://dx.doi.org/10.1016/j.cllc.2011.10.006 